\title{
Design, Synthesis, and Biological Evaluation of Camptothecin Loaded Biotinylated Cellulose Nanowhiskers as Anticancer Agents
}

\author{
Osamah N. Wennas*, Mohammed H. Mohammed', Raid M. Al Abood², and Dhulfiqar Ali Abed ${ }^{3,4}$
}

\author{
Department of Pharmaceutical Chemistry, College of Pharmacy, University of Baghdad, Baghdad, Iraq. \\ 2 Department of Pharmacy, Al Safwa University College, Karbala, Iraq. \\ ${ }^{3}$ Department of Pharmaceutical Chemistry, College of Pharmacy, University of Babylon, Babylon, Iraq. \\ ${ }^{4}$ Department of Medicinal Chemistry, Ernest Mario School of Pharmacy, Rutgers, The State University of New Jersey, 160 Frelinghuysen Road, Piscataway, NJ 08854, \\ United States) \\ *Correspondence to: Correspondence to: Osamah N. Wennas (E-mail: osamawennas@gmail.com) \\ (Submitted: 13 February 2021 - Revised version received: 28 March 2021 - Accepted: 12 April 2021 - Published online: 26 June 2021)
}

\begin{abstract}
Objective Using biotinylated cellulose nanowhiskers (CNWs), we designed and synthesized a Glutathione (GSH) sensitive- Camptothecin (CPT) prodrug for selective CPT delivery (compound 12).

Methods CPT-biotin (compound 9), was synthesized by direct conjugation of CPT to the biotin via GSH sensitive linkage to evaluate the role of CNWs in compound $\mathbf{1 2}$. The chemical structures of the synthesized prodrugs were confirmed by FT-IR, ${ }^{1} H$ NMR, ${ }^{13} \mathrm{CNMR}$, and ESI-MS, while the nanoparticles were characterized by DLS and TEM.

Results The in-vitro drug release assay demonstrated that only $18.6 \%$ of CPT was released from the nano conjugate under GSH stimulation at micromolar level $(100 \mu \mathrm{M})$, while $83.1 \%$ accumulative release rate was achieved under GSH stimulation at millimolar level (10 mM). The in-vitro cytotoxicity assay (MTT assay) demonstrated that compound 9 showed higher inhibition ratios on biotin positive cells, MCF-7, and HepG2, and lower cytotoxicity on biotin negative, CHO. Compound $\mathbf{1 2}$ showed good activity against MCF-7, HepG2, and much lower cytotoxicity on $\mathrm{CHO}$.

Conclusion This work demonstrates CPT-biotinylated cellulose nanowhiskers for selective chemotherapy and may have the potential to be used for cancer targeting.

Keywords Anticancer, camptothecin, cellulose nanowhiskers, biotin, glutathione.
\end{abstract}

\section{Introduction}

Cancer is a broad group of diseases that involves uncontrolled proliferation of abnormal cells that are capable of de-differentiation, invasion, and metastasis through the bloodstream or the lymphatic system..$^{1-5}$

Camptothecins, like camptothecin (CPT, 1, Figure 1) are regarded as one of the most promising anticancer drugs of the $21^{\text {st }}$ century. ${ }^{6}$ However, camptothecins have many challenges that need to be overcome. The problems include fast and $\mathrm{pH}$-dependent hydrolysis of the lactone structure to give inactive carboxylate form, poor water solubility, and low and variable oral bioavailability. ${ }^{7}$

Different approaches are being investigated to modulate camptothecins' systemic delivery, such as the development of prodrugs, or semi-synthetic analogs such as topotecan (2) and irinotecan (3), which are used clinically for the treatment of colon and ovarian cancers, respectively. Another approach is the polymer conjugates such as amphiphilic PEG-CPT conjugates $(4),{ }^{8,10}$ which improve the biological distribution, increase the body's retention times, reduce systemic toxicity, and improve the therapeutic efficacy. ${ }^{8,11}$ Cellulose molecules with at least one dimension within the nanoscale $(1-100 \mathrm{~nm})$ are considered as a nanocellulose. ${ }^{12}$ Nanocellulose can be divided into two main categories, cellulose nanowhiskers (CNWs), also known as cellulose nanocrystals (CNCs), and cellulose nanofibrils. ${ }^{13,14}$ Among them, CNWs drew a lot of attention due to their properties like a high degree of crystallinity, smaller nanoparticle sizes, and better dispersion. ${ }^{15} \mathrm{CNW}$ are considered interesting nanosize carriers for drug delivery because of their numerous advantages, like being biocompatible and not triggering an immune response. ${ }^{16}$ CNWs have high hydrophilicity that impedes opsonin proteins' adsorption. ${ }^{17}$ They are also suitable for different types of chemical linkages because the hydroxyl groups on the surface of CNWs can be easily modified to other chemical groups. ${ }^{18}$

In the current study, reduction-sensitive nanoparticles were designed from biotn- decorated CNWs- CPT with disulfide linkage. The presence of disulfide between the CNWs and $\mathrm{CPT}$ was suggested to release the active drug in response to the elevated intracellular GSH. Biotin has been used as targeting moiety with many anticancers to prevent the non-specific normal cells attack and to increase the uptake by the target cells. The in vitro drug release was studied at different GSH concentrations, and the cytotoxic effects of the nano conjugate on MCF7, HpeG2, and CHO cell lines were studied and compared with CPT prodrug without the nanocarrier.

\section{Materials and Methods}

\section{Materials}

Camptothecin, biotin, and 3,3'-dithiodipropionic acid were purchased from Beijing Yibai Biotechnology Co., Ltd. CNWs were purchased from the Process development center- The University of Maine U.S.A. Other chemicals were purchased 


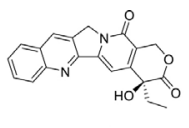

1
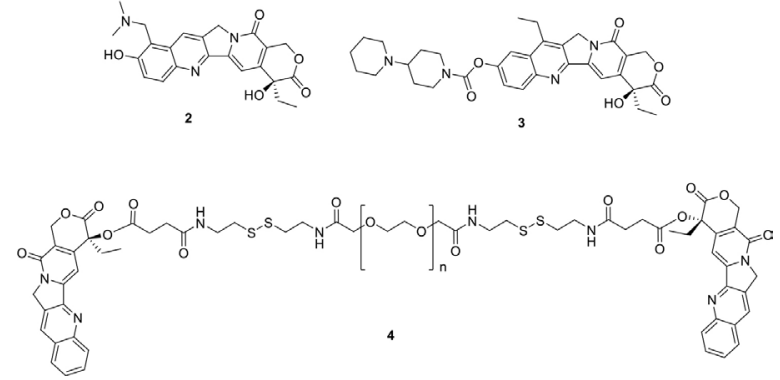

Fig. 1 Chemical structures of CPT and -some CPT analogs and prodrugs.

from Sigma-Aldrich. All chemicals are of analytical grade, and they were used as received without further purification.

\section{Characterization of Compounds 5-9 and Compound 11}

Melting points, Fourier transform infrared spectroscopy: FTIR, NMR: ${ }^{1} \mathrm{H}$ NMR and ${ }^{13} \mathrm{C}$ NMR spectra, and Electrospray ionization mass spectrometry: ESI-MS were performed for compound characterization.

\section{Chemical Synthesis}

The target compounds were synthesized by multi-step reactions, as shown in schemes $1 \& 2$.

\section{Synthesis of Biotin Methyl Ester (Compound 5)}

$0.75 \mathrm{~g}$ ( $3.075 \mathrm{mmol})$ of biotin was suspended in $75 \mathrm{~mL}$ methanol, $0.5 \mathrm{~g}$ of the catalyst (Amberlite IR-120 resin) was added, and the suspension was stirred at room temperature for $24 \mathrm{~h}$. After filtration and solvent's evaporation under reduced pressure, the title compound was obtained as a white powder, mp. $165-166^{\circ} \mathrm{C}$, yield $88 \% .{ }^{1} \mathrm{H}$ NMR $(500 \mathrm{MHz}$, DMSO-d6) $6.46(1 \mathrm{H}, \mathrm{s}), 6.38(1 \mathrm{H}, \mathrm{s}), 4.35-4.29(1 \mathrm{H}, \mathrm{m}), 4.14(1 \mathrm{H}, \mathrm{m})$, $3.59(3 \mathrm{H}, \mathrm{s}), 3.12(1 \mathrm{H}, \mathrm{dd}, \mathrm{J}$ 4.9, 3.2), $2.83(1 \mathrm{H}, \mathrm{dd}, \mathrm{J} 12.4,5.1)$ 2.59 (1 H, d, J 12.5), 2.31 (2 H, t, J 7.5), 1.68 - $1.42(4 \mathrm{H}, \mathrm{m})$, 1.35 (2 H, tt, J 14.3, 6.6). ${ }^{13} \mathrm{C}$ NMR (126 MHz, DMSO-d6) $173.78,163.22,61.52,59.68,55.81,51.66,40.33,33.57,28.48$ 28.44, 24.95. ESI (MS) Calcd for $\mathrm{C}_{11} \mathrm{H}_{19} \mathrm{~N}_{2} \mathrm{O}_{3} \mathrm{~S}(\mathrm{M}+\mathrm{H})^{+} 259.11$, found 259.3 .

\section{Synthesis of Biotin Hydrazide (Compound 6)}

$258 \mathrm{mg}$ ( $1 \mathrm{~mol}, 1.00$ equiv) of compound 5 was dispersed in $4 \mathrm{ml}$ of methanol, $0.5 \mathrm{~mL}$, (10 mmol, 10.0 equiv) of hydrazine was added. The suspension was stirred for $24 \mathrm{~h}$ at room temperature. The solvent was removed under reduced pressure, and the title compound was obtained as a white powder after washing with chloroform, mp. $245-247^{\circ} \mathrm{C}$, yield $90 \%$. ${ }^{1} \mathrm{H}$ NMR (500 MHz, DMSO-d6) $8.93(1 \mathrm{H}, \mathrm{s}), 6.44(1 \mathrm{H}, \mathrm{s})$, $6.37(1 \mathrm{H}, \mathrm{s}), 4.32(1 \mathrm{H}, \mathrm{dd}), 4.15(3 \mathrm{H}, \mathrm{m}), 3.10(1 \mathrm{H}, \mathrm{m}), 2.83$ (1 H, dd, J 12.4, 5.0), 2.59 (1 H, d, J 12.4), 2.02 (2 H, t, J 7.4), $1.67-1.41(4 \mathrm{H}, \mathrm{m}), 1.31(2 \mathrm{H}, \mathrm{tt}, \mathrm{J} 14.3,6.5) .{ }^{13} \mathrm{C}$ NMR $(126$ MHz, DMSO-d6) 172.02, 163.21, 61.52, 59.68, 55.89, 33.71,
28.70, 28.49, 25.70. MS (ESI) Calcd for $\mathrm{C}_{10} \mathrm{H}_{19} \mathrm{~N}_{4} \mathrm{O}_{2} \mathrm{~S}(\mathrm{M}+\mathrm{H})^{+}$ 259.12 , found 259.3 .

\section{Synthesis of 3,3'-Dithiodipropionic Anhydride (Compound 7)}

3,3'-dithiodipropionic acid $2 \mathrm{~g}$ was dissolved in $5 \mathrm{~mL}$ of acetyl chloride in a round bottom flask and refluxed at $65^{\circ} \mathrm{C}$ for $4 \mathrm{~h}$ until the solution was clear. After most of the solvent is removed under reduced pressure at $50^{\circ} \mathrm{C}$, iced ethyl ether was added to precipitate dithiodipropionic anhydride. After filtration and washing with petroleum ether, the title compound was obtained as a white powder, mp. $65-68^{\circ} \mathrm{C}$, yield $38 \%$.

\section{Synthesis of Camptothecin -3,3'-Dithiodipropionic Acid CPT-ss-COOH. (Compound 8)}

Compound 7 (1.923 g, $10 \mathrm{mmol})$ and compound 1 (0.348 g, $1 \mathrm{mmol})$ were dissolved in pyridine $(30 \mathrm{~mL})$, a solution of DMAP $(0.61 \mathrm{~g}, 5 \mathrm{mmol})$ in $10 \mathrm{~mL}$ of pyridine was added dropwise at $0{ }^{\circ} \mathrm{C}$ under nitrogen atmosphere. The reaction mixture was heated to $70^{\circ} \mathrm{C}$, and the reaction proceeded for $48 \mathrm{~h}$. Then, the reaction solution was precipitated by using an excess of methanol, washed with dilute $\mathrm{HCl}$, and dried to give the title compound as a yellow powder mp. $228-230^{\circ} \mathrm{C}$, yield $42 \% .{ }^{1} \mathrm{H}$ NMR (500 MHz, DMSO-d6) $8.66(1 \mathrm{H}, \mathrm{s}), 8.15(1 \mathrm{H}, \mathrm{d}, J$ 8.5), 8.10 (1 H, d, J 8.2), 7.89 - 7.82 (1 H, m), 7.70 (1 H, t, J 7.5), 7.18 (1 H, s), $5.51(2 \mathrm{H}, \mathrm{s}), 5.26(2 \mathrm{H}, \mathrm{s}), 3.09-2.89(6 \mathrm{H}, \mathrm{m}), 2.59$ (2 H, t, J 7.0), 2.18 (2 H, qd, J 7.2, 3.8), $0.92(3 \mathrm{H}, \mathrm{t}, J 7.4) .{ }^{13} \mathrm{C}$ NMR $\left(126 \mathrm{MHz}, \mathrm{DMSO}-d_{6}\right) 173.43,170.84,167.60,157.00$, 152.76, 148.36, 146.41, 145.71, 131.97, 130.87, 130.19, 129.42, $128.95,128.41,128.15,119.30,95.71,76.69,66.76,50.68$, 34.37, 33.72, 33.62, 32.90, 30.69, 8.06. MS (ESI) Calcd for $\mathrm{C}_{10} \mathrm{H}_{19} \mathrm{~N}_{4} \mathrm{O}_{2} \mathrm{~S}(2 \mathrm{M}+\mathrm{H})^{+}$1081.21, found 1081.00.

\section{Synthesis of Camptothecin-SS-Biotin Hydrazide (Compound 9)}

To a stirred solution of compound 8 (540 $\mathrm{mg}, 1 \mathrm{mmol})$ in 10 $\mathrm{mL}$ of DMF, EDC (288 mg, $1.5 \mathrm{mmol})$ and NHS (172 mg, $1.5 \mathrm{mmol}$ ) were added. The solution was stirred at room temperature for $1 \mathrm{~h}$ to form NHS ester of compound 8. Compound

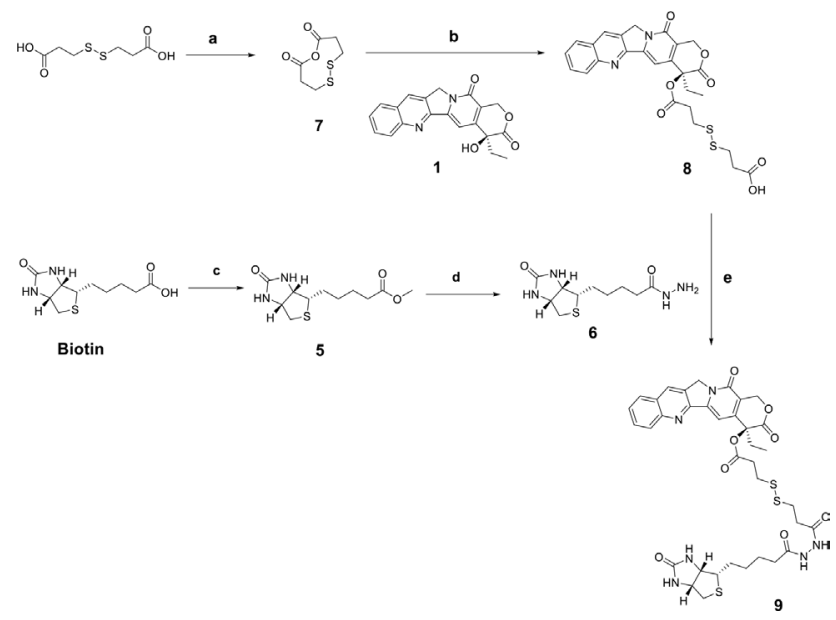

Scheme. 1 Synthesis schematics of compound 9. Reagents and conditions: (a) acetyl chloride, $65^{\circ} \mathrm{C}, 4 \mathrm{~h},(38 \%)$; (b) DMAP, pyridine, $70^{\circ} \mathrm{C}, 48 \mathrm{~h},(42 \%)$; (c) Amberlite IR 120 resin, methanol, rt, $24 \mathrm{~h}, 88 \%$; (d) hydrazine, methanol, rt, $24 \mathrm{~h}, 90 \%$; (e) EDC/ NHS, DMSO, rt, 48h, $72 \%$. 
6 (258 $\mathrm{mg}, 1 \mathrm{mmol}$ ) was added to the reaction solution, and the mixture was stirred at room temperature for $48 \mathrm{~h}$. The product was precipitated by the addition of water $(100 \mathrm{~mL})$. The product was purified by washing with dilute $\mathrm{HCl}$, and then dried to give the title compound as a white powder, mp. 234-236, yield 72\%. ${ }^{1} \mathrm{H}$ NMR (500 MHz, DMSO-d6) 9.85 (1 H, d, J 2.1), $9.74(1 \mathrm{H}, \mathrm{d}, J$ 2.1), $8.68(1 \mathrm{H}, \mathrm{s}), 8.17(1 \mathrm{H}, \mathrm{d}, J$ 8.5), 8.13 (1 H, d, J 8.2), 7.91 - $7.84(1 \mathrm{H}, \mathrm{m}), 7.72(1 \mathrm{H}, \mathrm{t}, J 7.6)$, $7.18(1 \mathrm{H}, \mathrm{s}), 6.41(1 \mathrm{H}, \mathrm{s}), 6.36(1 \mathrm{H}, \mathrm{s}), 5.51(2 \mathrm{H}, \mathrm{s}), 5.29$ $(2 \mathrm{H}, \mathrm{s}), 4.31(1 \mathrm{H}, \mathrm{m}), 4.12(1 \mathrm{H}, \mathrm{m}), 3.13-3.06(1 \mathrm{H}, \mathrm{m})$, 3.01-2.92 (6 H, m), 2.82 (1 H, dd, J 12.5, 5.1), $2.61-2.51$ (3 H, m), $2.18(2 \mathrm{H}, \mathrm{qd}, J$ 7.2, 3.8), $2.12(2 \mathrm{H}, \mathrm{t}, \mathrm{J} 7.4), 1.56-$ $1.43(4 \mathrm{H}, \mathrm{m}), 1.35(2 \mathrm{H}, \mathrm{tt}, J 14.3,6.5), 0.94(3 \mathrm{H}, \mathrm{t}, J 7.4) .{ }^{13} \mathrm{C}$ NMR (126 MHz, DMSO-d $)$ 171.35, 170.86, 169.41, 167.62, $163.17,157.02,152.80,148.37,146.43,145.69,132.02,130.92$, $130.25,129.45,128.99,128.45,128.19,119.33,95.70,76.67$, $66.78,61.50,59.66,55.87,50.71,33.93,33.65,33.42,33.39$, $32.82,30.72,28.55,28.48,25.51,8.06$. MS (ESI) Calcd for $\mathrm{C}_{10} \mathrm{H}_{19} \mathrm{~N}_{4} \mathrm{O}_{2} \mathrm{~S}(\mathrm{M}+\mathrm{H})^{+}$781.21, found 781.00.

\section{Synthesis of Carboxylated CNWs (CNW-COOH, Compound 10)}

$1.02 \mathrm{~g}$ of CNWs were suspended in $100 \mathrm{ml}$ of distilled water and sonicated for $5 \mathrm{~min} .29 .5 \mathrm{mg}, 0.188 \mathrm{mmol}$ of TEMPO, and $324 \mathrm{mg}, 3.15 \mathrm{mmol} \mathrm{NaBr}$ were added to the suspension. Then, $3.15 \mathrm{mmol}$ of $\mathrm{NaOCl}$ was added slowly to the cellulose suspension. The $\mathrm{pH}$ of the mixture was kept at $10-11$ by using $0.5 \mathrm{M}$ $\mathrm{NaOH}$ while stirring the suspension. After about $45 \mathrm{~min}$, the oxidation was terminated by adding $2 \mathrm{~mL}$ of methanol. $0.5 \mathrm{M}$ $\mathrm{HCl}$ was used to adjust the $\mathrm{pH}$ 7. The oxidized CNWs were dialyzed against deionized water for $48 \mathrm{~h}$. The concentration of the suspension was determined gravimetrically.

\section{Synthesis of Camptothecin -3,3'-Dithiodipropionic Hydrazide (Compound 11)}

Compound 8 (540 mg, $1 \mathrm{mmol}$ ) was dissolved in $15 \mathrm{ml}$ of DMF at room temperature. HOBt $(162 \mathrm{mg}, 1.2 \mathrm{mmol})$ and EDC (230 mg, $1.2 \mathrm{mmol}$ ) were added. The mixture was stirred at room temperature; the progress of the reaction was monitored by TLC. After $2 \mathrm{~h}$ when all the acid was converted to activated ester intermediates. The activated intermediate was then slowly added (by inverse addition) to a solution of hydrazine ( $2 \mathrm{mmol}$ ) and cyclohexene $(0.05 \mathrm{~mL})$ in DMF $(10 \mathrm{~mL})$ while the temperature was kept at $0-10{ }^{\circ} \mathrm{C}$. The reaction was complete upon the completion of the addition. The product was precipitated by the addition $100 \mathrm{~mL}$ of cold distilled water. After filtration, the product was washed with distilled water and dried to get the title compound as a yellow powder, mp. $215-218^{\circ} \mathrm{C}$, yield $61 \%$. ${ }^{1} \mathrm{H}$ NMR (500 MHz, DMSO- $\left.d_{6}\right) 9.06(1 \mathrm{H}, \mathrm{s}), 8.62(1 \mathrm{H}, \mathrm{s}), 8.13$ (1 H, d, J 8.6), 8.07 (1 H, d, J 8.3), $7.89-7.81$ (1 H, m), 7.67 (1 H, t, J 7.5), $7.17(1 \mathrm{H}, \mathrm{s}), 5.50(2 \mathrm{H}, \mathrm{s}), 5.22(2 \mathrm{H}, \mathrm{s}), 4.36$ $(2 \mathrm{H}, \mathrm{s}), 3.02-2.89(6 \mathrm{H}, \mathrm{m}), 2.51(2 \mathrm{H}, \mathrm{t}, J 7.1), 2.17(2 \mathrm{H}, \mathrm{qd}$ $J$ 7.2, 3.8), 0.93 (3 H, t, $J$ 7.6). ${ }^{13} \mathrm{C}$ NMR (126 MHz, DMSO- $\left.d_{6}\right)$ $170.88,169.91,167.62,156.97,152.71,148.32,146.38,145.71$, $131.94,130.86,130.11,129.40,128.91,128.36,128.12,119.31$, $95.69,76.67,66.78,50.63,34.30,33.65,32.78,30.72,8.07 . \mathrm{MS}$ (ESI) Calcd for $\mathrm{C}_{10} \mathrm{H}_{19} \mathrm{~N}_{4} \mathrm{O}_{2} \mathrm{~S}(\mathrm{M}+\mathrm{H})^{+} 555.13$, found 555.10.

\section{Synthesis of CPT-CNW-Biotin (Compound 12)}

$100 \mathrm{~mL}$ of compound 10 (0.74 W/V\%) was flocculated by adding $6 \mathrm{~mL}$ of saturated $\mathrm{NaCl}$, separated by centrifugation and rinsed (by redispersion, followed by centrifugation at $3000 \mathrm{rpm}$ for
$5 \mathrm{~min}$ ) three times with $50 \mathrm{~mL}$ of acetone, then two times with $50 \mathrm{~mL}$ of DMF. The pellets were dispersed in $100 \mathrm{~mL}$ of DMF and subjected to $5 \mathrm{~min}$ of sonication. The concentration of CNW$\mathrm{COOH}$ was determined gravimetrically $(0.65 \%$ containing $0.75 \mathrm{mmol}$ of COOH). $72 \mathrm{mg}$ of EDC $(0.37 \mathrm{mmol})$ and $43 \mathrm{mg}$ of NHS $(0.37 \mathrm{mmol})$ were added to activate half of the CNW$\mathrm{COOH}$. The suspension was stirred for $1 \mathrm{~h}$ at RT. $129 \mathrm{mg}$ (0.5 mmol) of compound 6 was added, and the suspension was stirred for $24 \mathrm{~h}$, and then the suspension was transferred to a dialysis tube and dialyzed against DMF for $24 \mathrm{~h}$ (3 times).

The suspension was transferred to a round bottom flask. $115 \mathrm{mg}$ of EDC $(0.6 \mathrm{mmol})$ and $69 \mathrm{mg}$ of NHS $(0.6 \mathrm{mmol})$ were added to activate the remaining $\mathrm{CNW}-\mathrm{COOH}$. The suspension was stirred for $1 \mathrm{~h}$ at RT. $333 \mathrm{mg}(0.6 \mathrm{~mol})$ of compound 11 was added, and the suspension was stirred for $24 \mathrm{~h}$ and then the suspension was transferred to a dialysis tube and dialyzed against DMF for $24 \mathrm{~h}$ (3 times) and then against DI water for $48 \mathrm{~h}$.

\section{Characterization of Nanoparticles}

\section{Conductometric Titration}

The carboxyl content of compound $\mathbf{1 0}$ was determined using conductometric titration, ${ }^{19}$ as shown in the titration curve (Figure 2).

\section{Determination of Biotin and CPT Content}

Elemental analysis was used to determine biotin content in compound $\mathbf{1 2}$ depending on the N\%; LECO elemental analyzer was used. The amount of CPT was determined by UV-visible spectrophotometer at $372 \mathrm{~nm}$ using Carry 100 device.

\section{Particle Size and Zeta Potential}

Horiba SZ100 instrument was used to determine the particle size and Zeta potential.

\section{Transmission Electron Microscopes (TEM)}

After sonication in a water bath, very diluted suspensions of the nanoparticles (0.001 wt.\%) were dropped on carbon film-covered copper grids. $2 \%$ uranyl acetate solution was

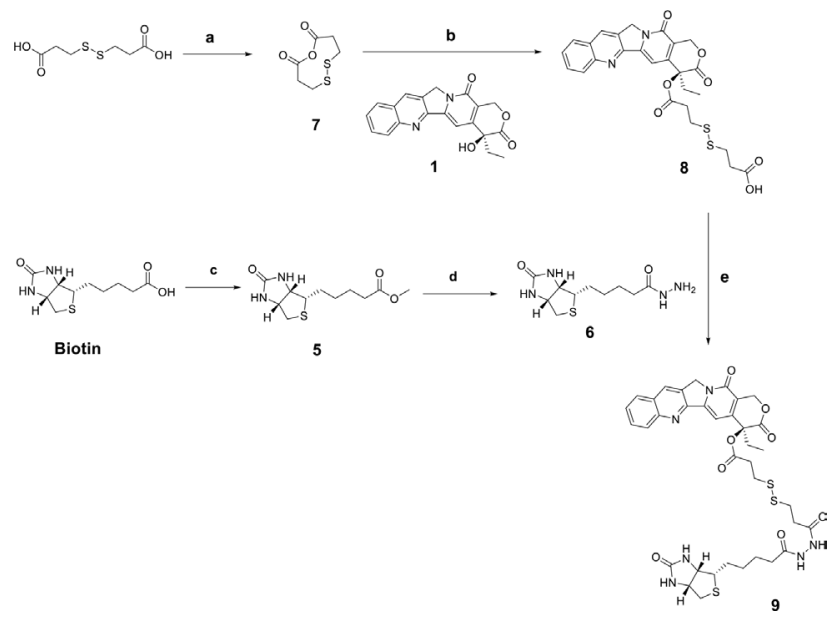

Scheme. 2 Synthesis schematics of compound 12. Reagents and conditions; (a) TEMPO, NaBr, NaClO, rt, 45 min; (b) HOBt, EDC, DMF, rt, $2 \mathrm{~h}$; (c) inverse addition of HOBt ester to hydrazine, DMF, cyclohexene 0-10oC, 78\%; (d) EDC, NHS, DMF, rt, 24 h. 
used for staining the samples on the grid, and the drying was done at ambient conditions. Then, the samples were examined by TEM (PHILIPS Model: CM120).

\section{In Vitro Drug Release Study}

The CPT release experiments were carried out at $37^{\circ} \mathrm{C}$. using two different media, acetate buffer ( $\mathrm{pH} 5.8$ ) with $10 \mathrm{mM} \mathrm{GSH}$ and phosphate buffer saline, pH 7.4 (FBS) with $100 \mu \mathrm{M}$ GSH to simulate the different microenvironments in cancer cells and blood vessels, respectively.

\section{In Vitro Cytotoxicity Assay}

The in vitro cytotoxicity of compounds 9 and 12 was evaluated by MTT assay on biotin-positive cell lines, human breast cancer cell (MCF-7) and human hepatic carcinoma (HepG2), and biotin negative cell line, noncancerous Chinese hamster ovarian (CHO). MTT was performed to determine the cytotoxic effect of the samples at various concentrations. The results were given as the mean of three independent experiments and the $\mathrm{IC}_{50}$ values were then calculated.

\section{Results}

\section{Chemical Synthesis of (5-9) and 11}

Compound $\mathbf{5}$ was prepared by the esterification of biotin with methanol in the presence of high excess of methanol according to Fischer esterification using Amberlite IR120 resign as acid catalysis. ${ }^{20}$ FT-IR showed the disappearance of carboxylic acid carbonyl stretching band $\left(1700 \mathrm{~cm}^{-1}\right)$ and the appearance of new band at $1743 \mathrm{~cm}^{-1}$ due to ester carbonyl stretching. ${ }^{1} \mathrm{H}$ NMR of the compound 5 was characterized by the disappearance of $\mathrm{COOH}$ proton signal at 12.00 p.p.m. and the appearance of a new signal as an indication of biotin's successful esterification, the signal was related to $\mathrm{COOC}_{3}$ protons at 3.59 p.p.m. as singlet.

Compound 6 was obtained by the hydrazinolysis of biotin methyl ester in methanol using an excess of hydrazine hydrate. ${ }^{21}$ FT-IR showed the disappearance of ester carbonyl stretching band $\left(1743 \mathrm{~cm}^{-1}\right)$ and the appearance of a new band at $1685 \mathrm{~cm}^{-1}$ due to hydrazide carbonyl stretching. ${ }^{1} \mathrm{H}$ NMR of compound $\mathbf{6}$ was characterized by the disappearance of $\mathrm{COOC} \underline{H}_{3}$ protons at 3.59 p.p.m. and the appearance of new signals to indicate the success of hydrazinolysis of compound 5, the signals were related to $\mathrm{CONHN} \underline{H}_{2}$ protons at 8.93 p.p.m. and 4.15 p.p.m. respectively both of them as a singlet.

Compound 7, the FT-IR showed the new bands at $1793 \mathrm{~cm}^{-1}$ and $1739 \mathrm{~cm}^{-1}$ due to asymmetric and symmetric stretching vibration of anhydride carbonyl. Compound $\mathbf{8}$ was obtained by the esterification of the hydroxyl of compound 1 with the anhydride (compound 7) using DMAP as an acylating catalyst. ${ }^{8}$ FT-IR showed a new band at $1720 \mathrm{~cm}^{-1}$ due to the carboxylic acid carbonyl stretching. ${ }^{1} \mathrm{H}$ NMR of compound 8 was characterized by the disappearance of alcoholic proton signal at 6.53 p.p.m. and the appearance of new signals to indicate CPT esterification's success; the signals related to aliphatic protons at 3.00-2.59 p.p.m.

Compound 9 was obtained by the conjugation of compound $\mathbf{8}$ and compound $\mathbf{6}$ (biotin hydrazide) using EDC as a coupling agent. ${ }^{22}$ FT-IR showed the disappearance of the carboxylic acid band at $1720 \mathrm{~cm}^{-1}$ due to amide formation. ${ }^{1} \mathrm{H}$ NMR of compound 9 was characterized by the disappearance of $\mathrm{CONHN} \underline{H}_{2}$ signal at 4.15 p.p.m. and the appearance of new signals that were related to CONHNHCO protons at 9.85 p.p.m. and 9.74 p.p.m. both of them as a singlet. Compound 11 was obtained by the reaction of compound 8 with hydrazine using HOBt and EDC as coupling agents. ${ }^{23}$ FT-IR showed the disappearance of the carboxylic acid band at $1720 \mathrm{~cm}^{-1}$ due to azide formation. ${ }^{1} \mathrm{H}$ NMR of compound $\mathbf{1 1}$ was characterized by the appearance of new signals to indicate the success of the reaction, the signals were related to $\mathrm{CON} \underline{H N H}_{2}$ protons at 9.06 p.p.m. and 4.36 p.p.m., respectively, both of them as a singlet.

\section{Characterization of Nanoparticles}

\section{Conductometric Titration}

The determination of carboxyl content of compound $\mathbf{1 0}$ was done using a method derived for the titration of cellulosic fibers by applying the following equation.

$[\mathrm{COOH}]=\left(\left(\mathrm{V}^{*} \mathrm{C} \mathrm{NaOH}\right) / \mathrm{m} \mathrm{CNWs}\right)-[\mathrm{OSO} 3 \mathrm{H}]$ in $\mathrm{mmol} \mathrm{kg}{ }^{-1}$

Where $\mathrm{V}$ is the volume of $\mathrm{NaOH}(14.63 \mathrm{~mL}), \mathrm{C}_{\mathrm{NaOH}}$ is the $\mathrm{NaOH}$ concentration $(0.01 \mathrm{~mol} / \mathrm{L}), \mathrm{m} \mathrm{CNWs}$ is the weight of the sample $(0.00015 \mathrm{~kg})$, and $\left[\mathrm{OSO}_{3} \mathrm{H}\right]$ was determined by elemental analysis and it was 175 mmole. By applying the equation, the $[\mathrm{COOH}]$ was calculated, and it was found to be $1150 \mathrm{mmole} / \mathrm{kg}$.

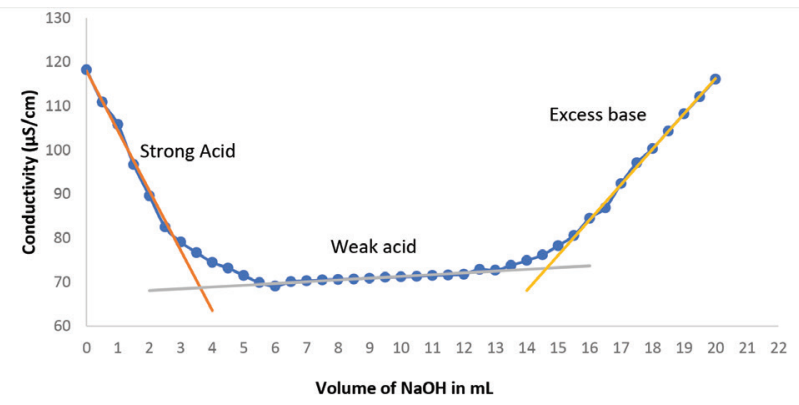

Fig. 2 Conductometric titration of compound 10.

Table 1: Characterization data of CNWs and CNW conjugates.

\begin{tabular}{cccccc}
\hline Sample & Particle size & PDI & Zeta potential & Biotin \% & CPT \% \\
\hline CNWs & $68.1 \pm 4.19$ & $0.383 \pm 0.124$ & $-34.33 \pm 1.59$ & - & - \\
Compound 10 & $81.23 \pm 0.3 .53$ & $0.462 \pm 0.052$ & $-65.2 \pm 2.40$ & - & - \\
Compound 12 & $87.26 \pm 3.496$ & $0.369 \pm 0.035$ & $-45.16 \pm 1.20$ & 8.67 & 5.6 \\
\hline
\end{tabular}



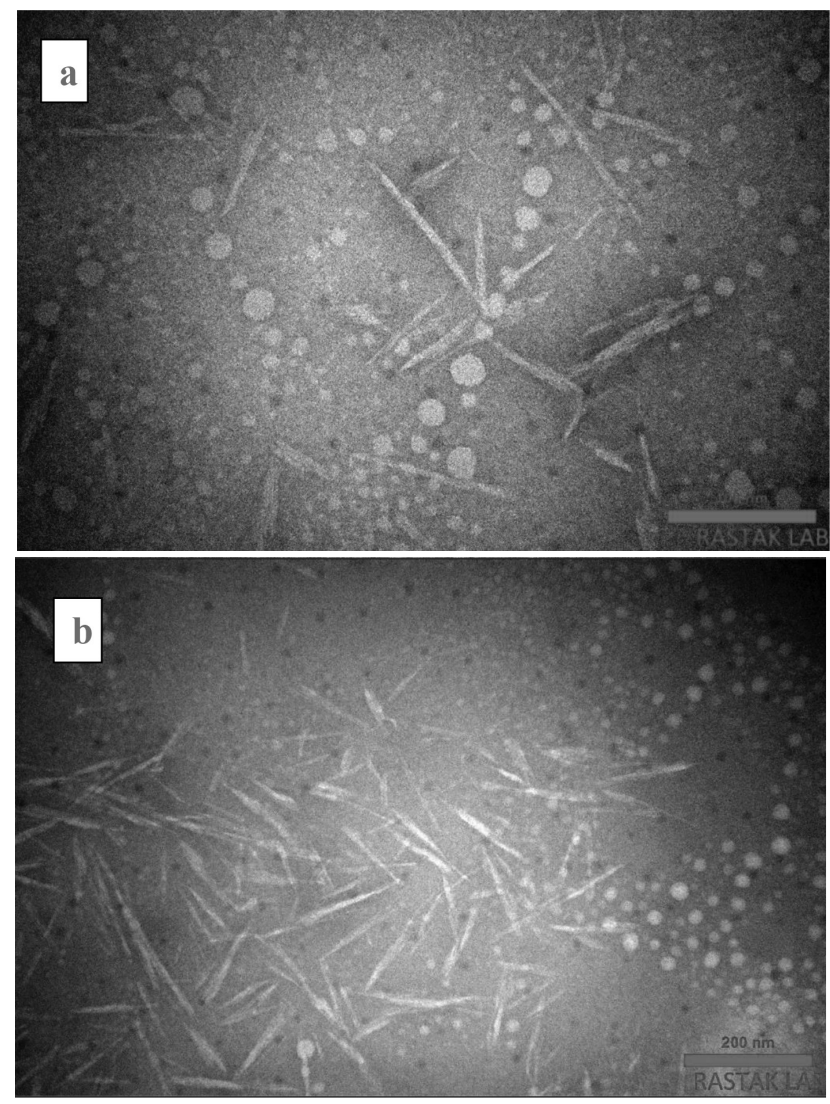

Fig. 3 TEM images of (a) CNWs (b) compound 12.

\section{Determination of Biotin and CPT Content}

The biotin and CPT contents of compound $\mathbf{1 2}$ were shown in Table 1.

\section{Particle Size and Zeta Potential}

The studies via DLS and zeta potential analysis revealed that the nanoparticles (CNWs, compounds 10, and 12) have a hydrodynamic radius between 68 and $87 \mathrm{~nm}$ and an overall negative surface charge, as shown in Table 1.

\section{Transmission Electron Microscopes}

Figure 3 shows the TEM images of CNWs, and compound 12. No significant changes in the morphology or the degree of agglomeration were observed.

\section{In Vitro Release Study}

The disulfide linkage between the CNWs and CPT can be cleaved readily in the presence of a reducing agent such as $\mathrm{GSH},{ }^{8}$ as shown in scheme $3 .{ }^{24}$

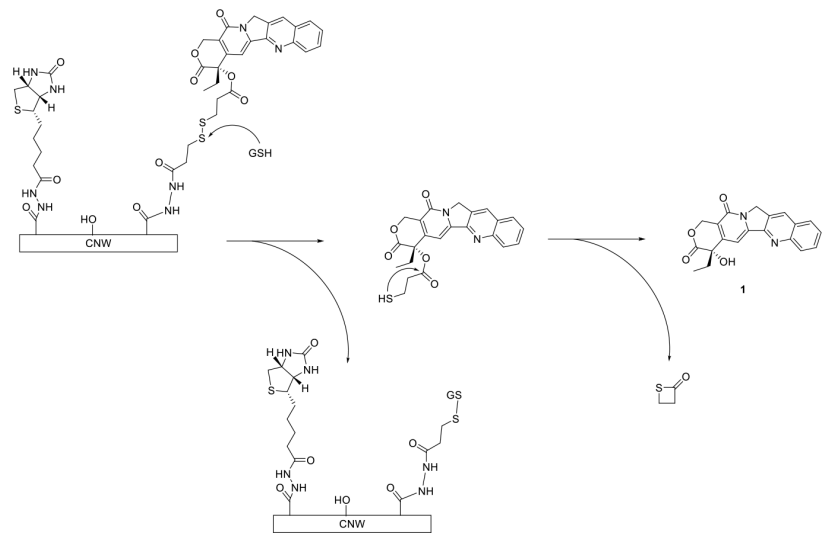

Scheme. 3 CPT release mechanism from compound 12.

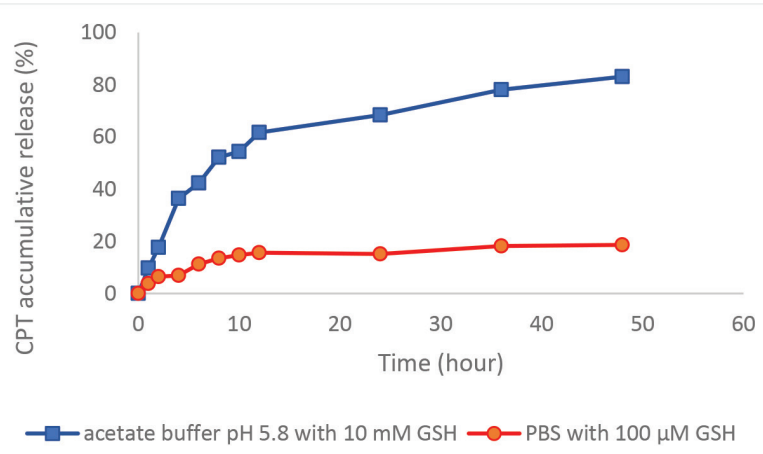

Fig. 4 Accumulative release of CPT from compound 12 at different conditions.

The accumulative release of CPT from compound $\mathbf{1 2}$ is only $18.6 \%$ in PBS with $100 \mu \mathrm{M}$ GSH after $48 \mathrm{~h}$, while the cumulative release in the acetate buffer medium pH 5.8 with $10 \mathrm{mM}$ GSH is $83.1 \%$, as shown in Figure 4 .

\section{In Vitro Cytotoxicity Assay}

The anticancer activity of compound $\mathbf{9}$, and compound $\mathbf{1 2}$ were examined in three cell lines with different expression levels of biotin receptor. MCF-7 and HepG2 cells overexpress biotin receptors on the surface, while biotin receptors were rarely expressed on $\mathrm{CHO}$ cells. ${ }^{25}$ Figure $5 \mathrm{a}$, b, and c show the viability of the cells after $72 \mathrm{~h}$ incubation. The half-maximal inhibitory concentration was determined to show the effectiveness of the tested compounds on growth inhibition of the three cell lines (Figure 5d). 

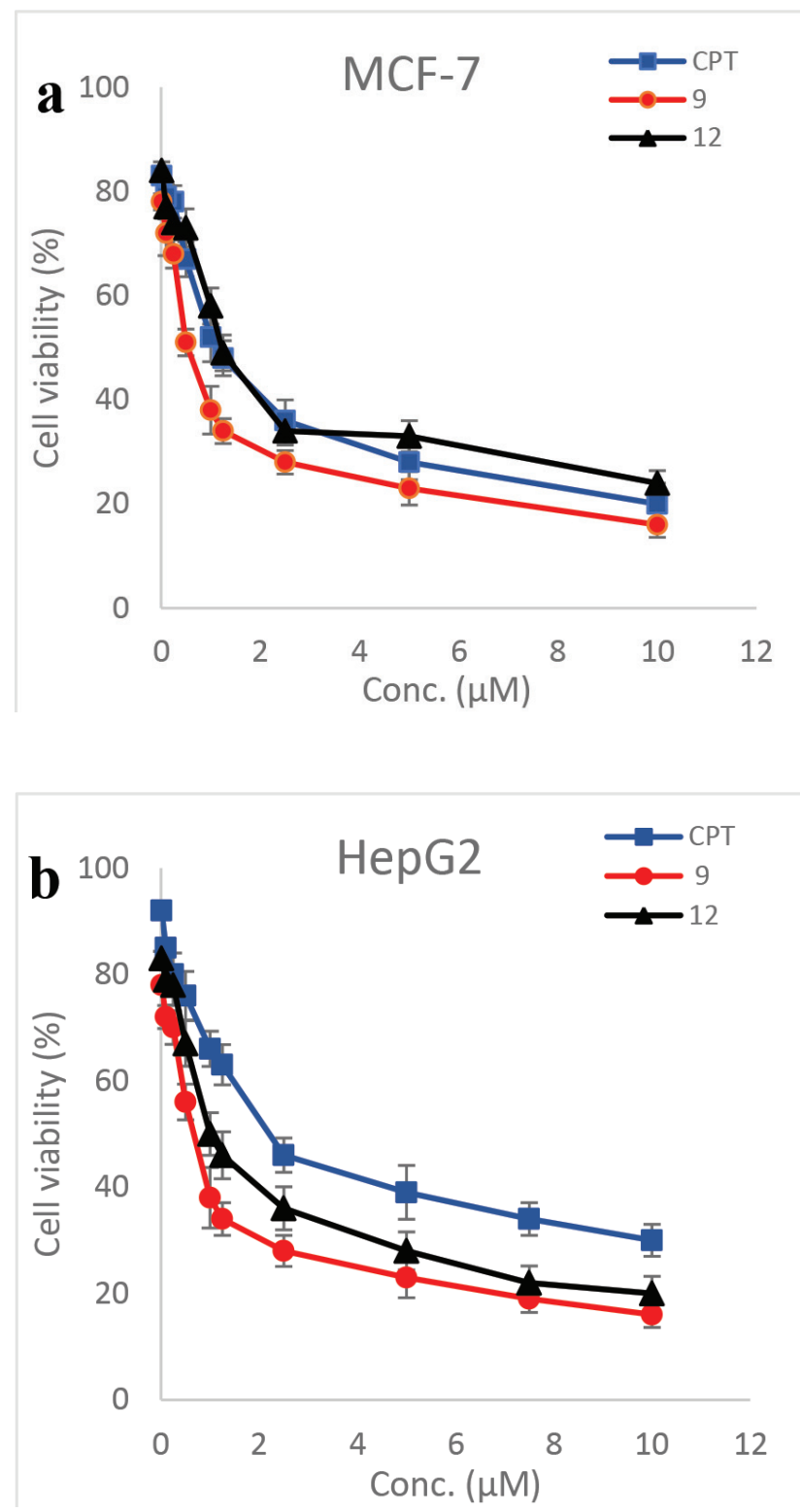

C

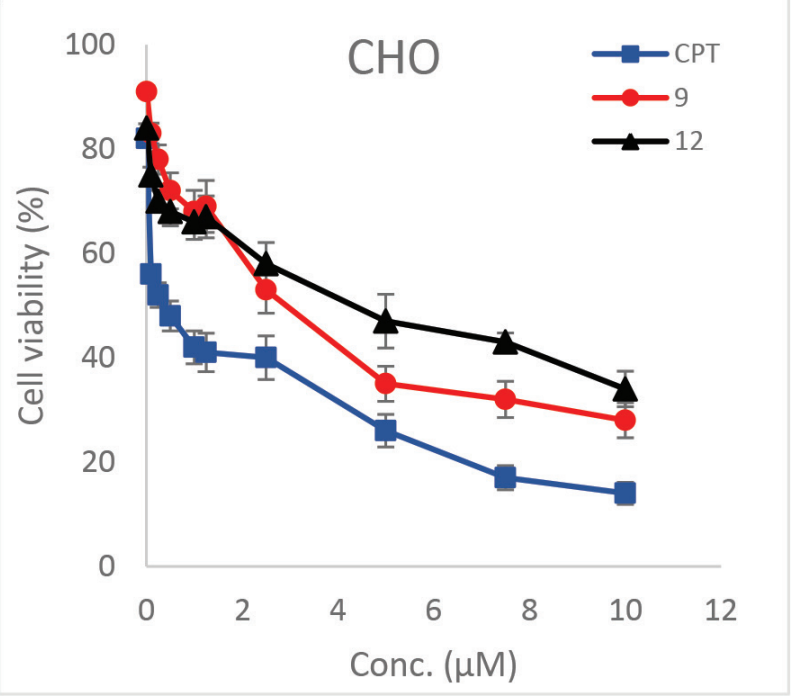

d

\begin{tabular}{|c|l|l|l|}
\hline & MCF-7 & HepG2 & CHO \\
\hline CPT & $1.1 \mu \mathrm{M}$ & $2.17 \mu \mathrm{M}$ & $0.46 \mu \mathrm{M}$ \\
\hline $\mathbf{9}$ & $0.51 \mu \mathrm{M}$ & $0.64 \mu \mathrm{M}$ & $3.24 \mu \mathrm{M}$ \\
\hline $\mathbf{1 2}$ & $1.22 \mu \mathrm{M}$ & $1.04 \mu \mathrm{M}$ & $4.83 \mu \mathrm{M}$ \\
\hline
\end{tabular}

Fig. 5 Cytotoxicity of free CPT, compound 9, and compound 12 against (a) MCF-7, (b) HepG2, and (c) CHO cells after incubation for $72 \mathrm{~h}(\mathrm{n}=3)$ (d) IC50s of free 6-MP, compound 9, and compound 12 in MCF-7, HepG2, and CHO cells.

\section{Discussion}

Chemical structure of the intermediates and the final compounds was confirmed using FT-IR, 1H NMR, 13C NMR, and ESI-MS. Characterization of nanoparticles was done using DLS and TEM. in Figure 4.

In vitro-release study results suggest that the release of CPT is accelerated in the cellular environment (especially tumors) with elevated GSH levels. In contrast, the release is minimum in the extracellular environment with a low GSH level.

Regarding the in vitro cytotoxicity, The $\mathrm{IC}_{50}$ of compound 9 is less than half or third of that of CPT in biotin positive cell lines, MCF-7 and HepG2, respectively, and about seven-folds higher than CPT for the biotin negative $\mathrm{CHO}$ cell line. For compound 12, it showed comparable activity to CPT against MCF-7 and higher activity against HepG2 with $\mathrm{IC}_{50}$ about half that of CPT, and much lower activity against $\mathrm{CHO}$ with $\mathrm{IC}_{50}$ is about eleven times higher than that of CPT. The relatively small molecule compound 9 has a cellular uptake by passive diffusion beside the cell endocytosis; conversely, compound $\mathbf{1 2}$ as a nanoparticle, mainly internalized only by cells endocytosis. These results suggest that the uptake and the cytotoxicity of compounds 9 and compound $\mathbf{1 2}$ were higher for cell lines with biotin overexpression than for cells with low biotin expression, and they can potentially reduce side effects of CPT by selectively killing biotin-positive tumor cells

\section{Conclusions}

In the recent decade, there have been several CPT-macromolecule prodrugs to address CPT limitations. However, there is still an unmet need to develop different types of macromolecule prodrugs to reduce systemic toxicity and improve the therapeutic efficacy. In the present study, we synthesized two CPT prodrugs using a biotin receptor and a GSH sensitive disulfide linker for intracellular delivery of CPT. The chemical structures of the synthesized prodrugs were confirmed by FT-IR, ${ }^{1} \mathrm{H}$ NMR, ${ }^{13} \mathrm{C}$ NMR, and ESI-MS, while the nanoparticles were characterized by DLS and TEM. The release study showed that GSH could promote the drug release at the intracellular millimolar level compared with GSH at a micromolar level. MTT assay demonstrated that this system 
had a higher inhibition ratio on biotin positive cells, MCF-7, and HepG2, and lower cytotoxicity on negative biotin cells, CHO. Therefore, these biotin-guided, GSH dependent prodrugs had the potential to be used for cancer targeting.

\section{Acknowledgments}

We thank the Department of Pharmaceutical Chemistry/College of Pharmacy/University of Baghdad for their official support in this study.

\section{Conflicts of Interest Disclosure}

There are no conflicts of interest.

\section{Competing Interests}

The authors declare that they have no competing interests.

\section{Source of Funding}

Self-funded project.

\section{References}

1. Ghorab, M.M.; El-Gazzar, M.G.; Alsaid, M.S. Synthesis and anti-breast cancer evaluation of novel N-(guanidinyl)benzenesulfonamides. Int. J. Mol. Sci. 2014, 15, 5582-5595, doi:10.3390/ijms15045582

2. Eggen, M.; Georg, G.I. The cryptophycins: Their synthesis and anticancer activity. Med. Res. Rev. 2002, 22, 85-101, doi:10.1002/med.10002.

3. Al-Amily, D.H.; Hassan Mohammed, M. Design, Synthesis, and Docking Study of Acyl Thiourea Derivatives as Possible Histone Deacetylase Inhibitors with a Novel Zinc Binding Group. Sci. Pharm. 2019, 87, 28, doi:10.3390/ scipharm87040028.

4. Al-Darraji, A.S.; Mohamed, M.H. Synthesis and preliminary anticancer evaluation of 6-mercaptopurine-methotrexate conjugate as possible mutual prodrug. Iraqi J. Pharm. Sci. 2019, 28, 114-124, doi:10.31351/ vol28iss1pp114-124.

5. Mohammed, M.H.; Taher, M.A. Synthesis of New Two Derivatives of 6-Mercaptopurine (6MP) 6-[5-Pyridine-4-yl- 1, 2, 3, 4-oxazolezole-2-yl) dithiol]-9H-purine (38) And 9H-purine-6-yl-benyldithiocarbamate (45) With Cytotoxicity Results From The National Cancer Institute's Anticancer Drug. Int J Pharm Sci Res 2012, 3, 2613-2622.

6. Sriram, D.; Yogeeswari, P.; Thirumurugan, R.; Ratan Bal, T. Camptothecin and its analogues: A review on their chemotherapeutic potential. Nat. Prod. Res. 2005, 19, 393-412, doi:10.1080/14786410412331299005.

7. Gupta, E.; Vyas, V.; Ahmed, F.; Sinko, P.; Cook, T.; Rubin, E. Pharmacokinetics of orally administered camptothecins. Ann. N. Y. Acad. Sci. 2000, 922, 195-204, doi:10.1111/j.1749-6632.2000.tb07038.x.

8. Liu, C.; Yuan, J.; Luo, X.; Chen, M.; Chen, Z.; Zhao, Y.; Li, X. Folate-decorated and reduction-sensitive micelles assembled from amphiphilic polymercamptothecin conjugates for intracellular drug delivery. Mol. Pharm. 2014, 11,4258-4269, doi:10.1021/mp500468d.

9. Mi, Z.; Burke, T.G. Differential Interactions of Camptothecin Lactone and Carboxylate Forms with Human Blood Components. Biochemistry 1994, 33, 10325-10336, doi:10.1021/bi00200a013.

10. Wang, J.; Cooper, R.C.; He, H.; Li, B.; Yang, H. Polyamidoamine Dendrimer Microgels: Hierarchical Arrangement of Dendrimers into Micrometer Domains with Expanded Structural Features for Programmable Drug Delivery and Release. Macromolecules 2018, 51, 6111-6118, doi:10.1021/acs. macromol.8b01006.

11. Paranjpe, P. V.; Chen, Y.; Kholodovych, V.; Welsh, W.; Stein, S.; Sinko, P.J. Tumortargeted bioconjugate based delivery of camptothecin: Design, synthesis and in vitro evaluation. J. Control. Release 2004, 100, 275-292, doi:10.1016/j. jconrel.2004.08.030.

12. loelovich, M. Cellulose as a nanostructured polymer: A short review. BioResources 2008, 3, 1403-1418, doi:10.15376/biores.3.4.1403-1418.

13. Isogai, A. Wood nanocelluloses: Fundamentals and applications as new biobased nanomaterials. J. Wood Sci. 2013, 59, 449-459, doi:10.1007/s10086013-1365-z.

14. Abitbol, T.; Rivkin, A.; Cao, Y.; Nevo, Y.; Abraham, E.; Ben-Shalom, T.; Lapidot, S.; Shoseyov, O. Nanocellulose, a tiny fiber with huge applications. Curr. Opin. Biotechnol. 2016, 39, 76-88.

15. Xu, X.; Liu, F.; Jiang, L.; Zhu, J.Y.; Haagenson, D.; Wiesenborn, D.P. Cellulose nanocrystals vs. Cellulose nanofibrils: A comparative study on their microstructures and effects as polymer reinforcing agents. ACS Appl. Mater. Interfaces 2013, 5, 2999-3009, doi:10.1021/am302624t.

16. Klemm, D.; Schumann, D.; Udhardt, U.; Marsch, S. Bacterial synthesized cellulose - Artificial blood vessels for microsurgery. Prog. Polym. Sci. 2001, 26, 1561-1603.

17. Lemarchand, C.; Gref, R.; Couvreur, P. Polysaccharide-decorated nanoparticles. Eur. J. Pharm. Biopharm. 2004, 58, 327-341, doi:10.1016/j. ejpb.2004.02.016

18. Eyley, S.; Thielemans, W. Surface modification of cellulose nanocrystals. Nanoscale 2014, 6, 7764-7779, doi:10.1039/c4nr01756k.

19. Fraschini, C.; Chauve, G.; Bouchard, J. TEMPO-mediated surface oxidation of cellulose nanocrystals (CNCS). Cellulose 2017, 24, 2775-2790, doi:10.1007/ s10570-017-1319-5.

20. Zör, K.I.; Amberl, O. Deactivation of Amberlite Ir-120 Used in the Esterification of Acetic Acid With Isobutanol. 2006

21. Murar, C.E.; Thuaud, F.; Bode, J.W. KAHA ligations that form aspartyl aldehyde residues as synthetic handles for protein modification and purification. J. Am. Chem. Soc. 2014, 136, 18140-18148, doi:10.1021/ja511231f.

22. Gong, X.Y.; Yin, Y.H.; Huang, Z.J.; Lu, B.; Xu, P.H.; Zheng, H.; Xiong, F.L.; Xu, H.X.; Xiong, $X . ; G u, X . B$. Preparation, characterization and in vitro release study of a glutathione-dependent polymeric prodrug Cis-3-(9H-purin-6-ylthio)acrylic acid-graft-carboxymethyl chitosan. Int. J. Pharm. 2012, 436, 240-247, doi:10.1016/j.jpharm.2012.06.043.

23. Zhang, X.; Breslav, M.; Grimm, J.; Guan, K.; Huang, A.; Liu, F.; Maryanoff, C.A.; Palmer, D.; Patel, M.; Qian, Y.; et al. A new procedure for preparation of carboxylic acid hydrazides. J. Org. Chem. 2002, 67, 9471-9474, doi:10.1021/ jo026288n.

24. Meng, X.; Gao, M.; Deng, J.; Lu, D.; Fan, A.; Ding, D.; Kong, D.; Wang, Z.; Zhao, Y. Self-immolative micellar drug delivery: The linker matters. Nano Res. 2018, 11,6177-6189, doi:10.1007/s12274-018-2134-5.

25. Ren, W.X.; Han, J.; Uhm, S.; Jang, Y.J.; Kang, C.; Kim, J.H.; Kim, J.S. Recent development of biotin conjugation in biological imaging, sensing, and target delivery. Chem. Commun. 2015, 51, 10403-10418, doi:10.1039/ c5cc03075g. 